\title{
A PRESCRIÇÃO PENAL APÓS O ADVENTO DA \\ LEI No 12.234/10, E SUA RELAÇÃO COM OS \\ DEVERES DE PROTEÇÃO ESTATAL
}

Anelise Coelho Nunes

Doutora em Direito - PUCRS - Professora da Estácio Rio Grande do Sul anelise. nunes@estacio.br

Mateus Marques Conceição

Doutorando em Direito - UNISINOS - Professor da Estácio Rio Grande do Sul. mateus.conceicao@estacio.br

\section{Resumo}

As alteraçóes promovidas pela vigência da Lei no 12.234/10 trouxeram algumas controvérsias no que se refere a uma possível extinção a prescrição (na modalidade) retroativa. Nesse sentido, o texto permite estabelecer um parâmetro de discussão, com garantia, que o legislador optou por conferir efeito ex tunc à prescrição da pretensão punitiva, com base na pena concreta, apenas a partir do recebimento da denúncia ou queixa. Dessa forma, necessário é o presente estudo no sentido de tratar acerca da participação democrática do Estado em relação ao dever fundamental de proteção, que, por meio de lei, ato administrativo ou atuação fática, está obrigado, a atuar positivamente para impedir coibir práticas atentatórias a direitos fundamentais.

\section{Palavras-chave}

Prescrição Penal; Lei n 12.234/10; Pena; Garantias Fundamentais; Dever Estatal de Proteção.

\section{Resúmen}

Los cambios introducidos por la promulgación de la Ley $n^{\circ}$ 12.234 /10 trajeron una cierta controversia con respecto a una posible prescripción de la extinción (en forma) retroactivo. En este sentido, el texto permite establecer un parámetro de la discusión, con la garantía de que el legislador optó por dar efecto ex tunc a la prescripción de la pretensión punitiva, en base a la sanción específica, sólo desde la recepción de la queja o reclamación. Por lo tanto, este estudio es necesario para tratar sobre el deber fundamental 
de la protección del Estado, que, por ley, acto administrativo o acciones de hecho, está obligado a actuar positivamente para evitar prácticas aceras sean perjudiciales para los derechos fundamentales.

\section{Palabras clave}

Prescripción penal; Ley no 12.234/10; Sanción penal; Garantías Fundamentales; Deber de Protección del Estado.

\section{Introdução}

O presente estudo tem como finalidade tratar sobre questão de relativa importância no âmbito do Direito Penal. Com o advento da Lei n ${ }^{\circ} 12.234 / 10$ o legislador deu novo significado ao tema da prescriçấo retroativa da pena. Assim, em um primeiro momento é necessário que tratemos de questão fundamental, o dever estatal de proteção, ou seja, ato em que o Estado se obriga a coibir técnicas atentatórias e violadoras de garantias e direitos fundamentais.

Ainda, necessário é que se analise os princípios e pressupostos constitucionais de proteção em relação ao tema central da presente discussão acadêmica, relacionando as alteraçóes legislativas brasileiras com o direito espanhol.

\section{Aspectos Importantes sobre o Dever Estatal de Proteção}

Segundo Robert Alexy (2012, p.433), ao lado dos direitos de defesa, que se destinam a proteger o indivíduo contra intervençôes do Poder Público - e, nesse sentido, são direitos a uma ação negativa (abstenção) do Estado-, existem direitos a prestaçóes estatais dispositivas (direitos a prestaçóes em sentido amplo), que impóem ao Estado a persecução de determinados objetivos e compreendem prestaçóes fáticas (ou materiais) e prestaçóes normativas.

Dentre esses direitos e prestaçóes estatais em sentido amplo, destacam-se os chamados direitos de proteção, entendidos como os direitos do titular de direitos fundamentais em face do Estado a que este o proteja contra intervençóes de terceiros. Eles impóem ao Estado uma obrigação de proteger ou fomentar a algo, por meio de prestaçóes de natureza jurídica e de natureza fática. Não são apenas a vida e a saúde os bens passíveis de serem protegidos, mas tudo aquilo que seja digno de proteção a partir do ponto de vista dos direitos fundamentais, como a dignidade, a liberdade, a família, a propriedade (ALEXY, 2012, p.450).

Fala-se, portanto, em dever fundamental de proteção do Estado, que, por meio de lei, ato administrativo ou atuação fática, está obrigado, a atuar positivamente para impedir que um indivíduo viole direitos fundamentais de outro (BOROWSKI, 2003, p.112). 
Por força desse dever, de acordo com Gilmar Mendes e Paulo Gustavo Branco (2014, p. 160), o Estado está obrigado a editar normas penais para coibir práticas atentatórias a direitos fundamentais. Já, como anota Anibal Bruno (2005, p.5), a finalidade do Direito Penal é:

“(...) a defesa da sociedade, pela proteção de bens jurídicos fundamentais, como a vida humana, a integridade corporal do homem, a honra, o patrimônio, a paz pública, etc. (...) O que se manifesta no exercício da Justiça Penal é esse poder soberano do Estado, um poder jurídico que se faz efetivo pela lei penal, para que o Estado cumpra a sua função originária, que é assegurar as condiçôes de existência e continuidade da organização social”.

Para Santiago Mir Puig (2002, p.47), o Direito Penal, entendido como o conjunto de normas que associam ao delito, como pressuposto, penas ou medidas de segurança, como consequência jurídica, é um dos instrumentos de controle social mais importantes, da sociedade, tendente a evitar determinados comportamentos que se reputam indesejáveis, mediante a ameaça de imposição de distintas sanções, senão vejamos:

"pode-se discutir qual ou quais são as funçóes que se atribuem à pena - retribuição e prevenção - mas é inegável que se trata de um mal que se associa ao cometimento de um delito, seja porque se crê que, com tal mal, se faz justiça, seja porque, com sua ameaça, pretende-se dissuadir a prática de delitos".

Como lembra Jeschek (1981, p.3), a missão do direito Penal é proteger a convivência humana em sociedade. Como ordem de paz e de proteção das relaçóes sociais humanas, tem importância fundamental, uma vez que visa assegurar a inquebrantabilidade da ordem jurídica por meio da coação estatal, exercendo uma função repressiva e uma função preventiva. Assim, "toda pena deve contribuir para fortalecer novamente no condenado o respeito pelo Direito e a fazer com que regresse, por si mesmo e por seu próprio convencimento, ao caminho da ordem".

Nesse sentido, aduz Santiago Mir Puig (2002, p.47) que a efetiva execuçáo da pena, além do caráter retributivo, de prevenção especial e de ressocializaçáo, atinente ao condenado, não deixa de exercer relevante função de prevenção geral, não apenas do ponto de vista da pura intimidação negativa (isto é, inibidora da tendência a delinquir), como também pela afirmação positiva do Direito Penal, que se manifesta: a) pela função informativa do que está proibido fazer; b) pelo reforço, no seio social, da confiança no sistema de justiça criminal e na capacidade de a ordem jurídica de se impor; e c) pelo fortalecimento, na maioria dos cidadãos, de uma atitude de respeito pelo Direito.

Segundo Jeschek (1981, p.18), 
"pena é a compensação a uma violação do Direito cominada penalmente mediante a imposição de um mal proporcional à gravidade do injusto e à culpabilidade que expressa a reprovaçáo pública do fato e consegue, deste modo, a afirmação do Direito".

O ilustre penalista alemão afirma que a justificação da pena reside na sua necessidade para manter a ordem jurídica, como condição fundamental para a convivência humana em sociedade:

"o Poder do Estado se aniquilaria por si mesmo, se não tivesse força suficiente para impedir que as infraçôes jurídicas intoleráveis se afirmassem abertamente. Sem a pena o Ordenamento Jurídico deixaria de ser uma ordem coativa e quedaria rebaixado ao nível de uma simples recomendação não vinculante. A pena, como expressão da coação jurídica, forma parte de toda comunidade baseada em normas jurídicas (justificação jurídicopolítica da pena). A pena é ademais necessária para satisfazer a sede de justiça da comunidade. Uma convivência humana pacífica seria impossível se o Estado se limitasse simplesmente a defender-se dos delitos cuja comissão fosse iminente e pretendesse que tanto da vítima como da generalidade, que aceitassem o delito cometido e vivessem com o delinquente como se nada houvesse se passado. As consequências dessa atitude levariam a que cada um tomasse a justiça pelas próprias máos e o regresso à pena privada (justificação psicosociológica da pena)". (JESCHEK, 1981, p.18)

Pela prevenção especial, diz Aníbal Bruno (1967, p.49),

“(...) procura-se evitar que novos crimes ocorram, por ação exercida sobre o próprio delinquente (...). Aí também se pode fazer sentir, como na prevenção geral, a força da intimidação. O criminoso mostrou-se indiferente à ameaça da pena, mas a sua aplicação e execução podem agir de modo mais eficaz. A sanção penal já não é uma abstração da lei, cujas verdadeiras consequências não podem ser percebidas; é uma realidade cujos efeitos penosos o réu está sofrendo e pode temer voltar a sentir”.

Transformar a abstraçáo normativa nessa realidade diz respeito à efetividade da norma penal.

Assim, leciona Hans Kelsen (1991, p.1),

"como a vigência da norma pertence à ordem do dever- ser, e não à ordem do ser, deve também distinguir-se a vigência da norma de sua eficácia, isto é, do fato real de ela ser efetivamente aplicada e observada, da circunstância de uma conduta humana conforme à norma se verificar na ordem dos fatos". 
"uma Constituição é eficaz se as normas postas de conformidade com ela são, globalmente e em regra, aplicadas e observadas”.

Luís Roberto Barroso (2009, p.82), ao tratar da eficácia social da norma, aduz, com apoio em Kelsen, que:

"[a] efetividade significa a realização do Direito, o desempenho concreto de sua função social. Ela representa a materialização, no mundo dos fatos, dos preceitos legais e simboliza a aproximação, tâo íntima quanto possível, entre o dever/ser normativo e o ser da realidade social. Assim, ao jurista cabe formular estruturas lógicas e prover mecanismos técnicos aptos a dar efetividade às normas jurídicas".

A Lei $n^{\circ} 12.234 / 2010$ visa exatamente concretizar, em justa medida, o dever estatal de proteçáo a direitos fundamentais da coletividade e conferir maior efetividade às normas penais que os tutelam e à prestação jurisdicional.

Nesse contexto, assegura-se a efetividade da execução de uma pena lealmente prevista e regularmente imposta, em processo no qual tenham sido respeitadas, dentre outras, as garantias constitucionais do juiz natural, do devido processo legal, da presunção de inocência, do contraditório e da ampla defesa, mediante sua imunização contra os efeitos retroativos da prescrição da pretensão punitiva entre a data do fato e o recebimento da denúncia ou queixa, não importa em violação à dignidade da pessoa humana (art. $1^{\circ}$, III, CF) e seu consectário, o princípio da humanidade das penas, cujo principal escopo é vedar a imposição de penas cruéis, degradantes de trabalhos forçados, de caráter perpétuo ou de morte (art. 5, XLVII, CF) e assegurar ao preso o respeito à sua integridade física e moral (art. 5, XLIX, CF).

$\mathrm{O}$ acusado não deixa de ser tratado como pessoa humana pelo simples fato de se conferir maior efetividade à sanção penal, mesmo porque, afirmada a sua responsabilidade criminal, há o "dever de submeter-se às consequências jurídicas do crime" (MIR PUIG, 2002, 727).

Nesse sentido e segundo a lição de José Frederico Marques (1999, p.148),

"humanizar a pena não é o mesmo que inocuizá-la como castigo e retribuição. As sançóes penais devem ser temidas para que a pena consiga atingir suas finalidades de prevenção geral. A humanização do Direito Penal não pode ultrapassar as fronteiras da retribuição para transformar em prêmio a sanção punitiva e os cárceres em luogo di piacere. $\mathrm{O}$ condenado deve ser tratado com humanidade. Náo se permite que o castigo imposto venha a ser instrumento de iniquidade e degradação; necessário se faz, no entanto, que a pena, como um mal que o delinquente deve sofrer, não se dilua e desapareça no tratamento conferido ao condenado".

Precisas, ainda, as palavras de Paulo José da Costa Júnior (2002, p. XIX): 
“a pena, para exercer sua função intimidadora, deverá ser certa. É a advertência que já fazia o Marques Cesare de Beccaria, muitos anos atrás. O réu deverá compenetrar-se de que, praticado o crime, será certamente punido com uma sançáo justa e proporcional ao mal causado.

Há os que póem em dúvida o caráter intimidativo da pena (...).

Mas a pena, quando for certa, intimida sim. Veja-se o caso das infrações de trânsito, cujas sançóes são certas, tecnicamente aplicadas, mediante radares colocados em ruas e estradas. São elas inapeláveis. Registram a infração, que se segue de multa e mesmo de perda da carteira de habilitação do motorista, se os pontos forem superiores a vinte. Mediante a certeza da aplicação da pena e da perda da carteira, os delitos de trânsito diminuíram sensivelmente.

É a prova evidente de que a pena, quando certa, intimida, detém, o infrator na senda delituosa.

O direito penal, para intimidar, deverá munir-se da certeza da execução (...)".

Não há dúvida, por outro lado, de que a Lei no 12.234/2010 importa numa intervenção no direito de liberdade.

Com efeito, ao determinar que, entre a data do fato e o recebimento da denúncia ou queixa - que continua a operar como marco interruptivo da prescrição (art. 117, I, CP) -, a prescrição seja calculada com base na pena em abstrato, e não na pena aplicada na sentença, a lei reduz a probabilidade e extinção da punibilidade do agente pela prescrição da pretensão punitiva.

Resta agora submetê-la ao exame da proporcionalidade, para se aferir se há justificação constitucional para esta intervenção.

\section{A Proporcionalidade em Sentido Amplo}

Não cabe, nesta seara, ingressar no tormentoso campo da terminologia relativa à proporcionalidade, para definir se é critério, princípio (SERRANO, 1990, p.16), regra (SILVA, 2002, p.24), máxima (ALEXY, 2012, p.117) ou postulado normativo aplicativo, regra de segundo nível ou meta-regra (ÁVILA, 2011, p.145).

Importa, mais do que a terminologia, a correta estruturação e aplicação a proporcionalidade. Nesse sentido, a proporcionalidade em sentido amplo se distingue da razoabilidade em função de sua origem e estrutura de aplicação.

A razoabilidade ou, mais, precisamente, o "princípio da irrazoabilidade", tem origem na jurisprudência inglesa que, a partir de decisão proferida em 1948 passou a rejeitar atos ou decisôes que fossem excepcionalmente irrazoáveis, que nenhuma autoridade razoável 
adotaria. Trata-se, portanto, de um "teste de irrazoabilidade", para se aferir se a Corte tem ou não legitimidade para glosar o ato impugnado (SILVA, 2002, p.27).

Costuma-se ainda associar a proporcionalidade à razoabilidade da jurisprudência da Suprema Corte norte-americana, baseada no devido processo legal em sentido material, previsto, em nosso ordenamento, no art. 5 LIV, da Constituição Federal (SILVA, 2002, p.27).

O exame da proporcionalidade propriamente dito, por sua vez, tem origem na jurisprudência do Tribunal Constitucional alemão (SILVA, 2002, p.34). Como observa Virgílio Afonso da Silva (2002, p. 26), embora a proporcionalidade e razoabilidade tenham objetivos semelhantes, esses temos não são sinônimos, tanto que um ato pode ser considerado desproporcional - v.g., uma leve intervenção em um direito fundamental, desprovida de fundamentação constitucional - sem ser absurdamente irrazoável. Logo, ainda que se queira, por intermédio de ambos, controlar as atividades legislativa ou executiva, limitando-as para que não restrinjam mais do que o necessário os direitos dos cidadãos, esse controle é levado a cabo de forma diversa, caso seja aplicado um ou outro critério.

Com efeito, diferentemente da razoabilidade, o exame da proporcionalidade tem uma estrutura racionalmente definida, com sub-regras (SILVA, 2002, 27), ou conforme a terminologia adotada, submáximas, subelementos, subcritérios ou subprincípios independentes, que são aplicadas, de acordo com Carlos Bernal Pulido (2007, p. 692), de maneia sucessiva e escalonada.

Há, portanto uma ordem pré-definida para sua aplicação: idoneidade (ou adequação), necessidade e proporcionalidade em sentido estrito. Nas palavras de Virgílio Afonso da Silva (SILVA, 2002, p. 30),

"se simplesmente as enumeramos, independentemente de qualquer ordem, pode-se ter a impressáo de que tanto faz, por exemplo, se a necessidade do ato estatal é, no caso concreto, questionada antes ou depois da análise da adequaçáo e da proporcionalidade em sentido estrito. Não é o caso. A análise da adequaçáo precede a da necessidade, que, por sua vez, precede a da proporcionalidade em sentido estrito.

A real importância dessa ordem fica patente quando se tem em mente que a aplicação da regra da proporcionalidade nem sempre implica a análise de todas as suas três sub-regras. Pode- se dizer que tais sub-regras relacionam-se de forma subsidiária entre si entre si. Essa é uma importante característica, para a qual não se tem dado a devida atenção. A impressão que muitas vezes se tem, quando se mencionam as três sub-regras da proporcionalidade, é que o juiz deve sempre proceder à análise de todas elas, quando do controle do ato considerado abusivo. Náo é correto, contudo, esse pensamento. É justamente na relação de subsidiariedade acima mencionada que reside a razão de ser da divisão em sub-regras. Em termos 
claros e concretos, com a subsidiariedade quer-se dizer que a análise da necessidade só é exigível, e somente se, o caso já não tiver sido resolvido com a análise da adequação; e a análise da proporcionalidade em sentido estrito só é imprescindível, se o problema já não tiver sido solucionado com as análises da adequação e da necessidade. Assim, a aplicação da regra da proporcionalidade pode esgotar-se, em alguns casos, com o simples exame da adequação do ato estatal para a promoção dos objetivos pretendidos. Em outros casos pode ser indispensável a análise acerca de sua necessidade. Por fim, nos casos mais complexos, e somente nesses casos, deve-se proceder à análise da proporcionalidade em sentido estrito".

A observância dessa ordem pré-definida para aplicação de suas sub-regras é que torna racional, e não fruto de intuição ou decisionismo judicial, o exame da proporcionalidade.

\subsection{Do Exame da Idoneidade (ou Adequação)}

De acordo com a sub-regra da idoneidade (ou adequação), toda intervenção em um direito fundamental deve ser apta a promover, a fomentar a realização de um fim constitucionalmente legítimo. Não se exige que ela realize por completo esse fim, mas, tão somente, que se mostre idônea a favorecer a sua obtenção (PULIDO, 2007, p.693).

É suficiente, nesse exame da simples relação e causalidade empírica entre meio e fim (GAVIÃO FILHO, 2011, p.241), que o meio, nas palavras de Humberto Ávila, possa contribuir para a promoção gradual do fim, que o promova minimamente, mesmo que não seja o mais intenso, o melhor nem o mais seguro (ÁVILA, 2011, p.177).

Um fim, é considerado constitucionalmente legítimo quando a sua consecução é ordenada ou permitida pela Constituição, e ilegítimo quando por ela seja proibido, explícita ou implicitamente (PULIDO, 2007, p.696).

Na espécie, o fim da Li 12.234/2010 é promover uma maior efetividade das normas penais incriminadoras e da tutela jurisdicional penal, razão por que é constitucionalmente legítimo, na esteira do dever estatal de proteção a direitos fundamentais da coletividade.

Por sua vez, o meio escolhido - impedir o reconhecimento da prescrição da pretensão punitiva pela pena concretizada, na modalidade retroativa, entre a data do fato e o recebimento da denúncia ou queixa -, é apto, idôneo a promover a realização daquele fim.

Portanto, o art. 110, $\$ 1^{\circ}$, do Código Penal, na redação dada pela Lei no $12.234 / 2010$, supera, com êxito, o exame da idoneidade (adequação).

\subsection{Sobre o Exame da Necessidade}

O exame da necessidade impóe a verificação da existência de meios que sejam alternativos àquele escolhido pelo Poder Legislativo, e que possam promover igualmente o fim 
sem restringir, na mesma intensidade, os direitos fundamentais afetados (ÁVILA, 2011, p.182).

Trata-se de um teste comparativo, de consideração as medidas alternativas que pudessem promover o mesmo fim (SILVA, 2002, p.171), haja vista que uma medida não será necessária se a sua finalidade também puder ser alcançada por outro meio aos menos igualmente eficaz e que não restrinja o direito fundamental afetado ou restrinja-o com uma intensidade menor (BOROWSKI, 2003, p. 130).

Em se tratando de lei, como observa Carlos Bernal Pulido (2007, p.748),

"a busca de meios alternativos pode ser interminável; esse afã conhece unicamente os limites da imaginação. Sem embargo, o Tribunal Constitucional deve escolher alguns, a fim de poder levar a cabo o exame da necessidade. Para esse efeito, o Alto Tribunal deve selecionar aqueles que, de acordo com os conhecimentos científicos, técnicos, dogmáticos e gerais, existentes no momento da expedição da norma legislativa examinada, teriam podido ou poderiam ser idôneos de alguma maneira a contribuir à obtenção do fim legítimo perseguido pelo Parlamento (...)”.

Quais seriam, portanto, os meios alternativos que, hipoteticamente, se revestiriam de algum grau de idoneidade para alcançar o fim a que se propóe a Lei no $12.234 / 2010$ ?

Para Luis Prieto Sanchís (2009, p.204), quando se questiona a possível existência de outras intervençóes menos gravosas, o juiz, deve assumir o papel de um diligente legislador na busca do meio mais apropriado.

Assim, na comparação entre as medidas potencialmente idôneas, duas são as variáveis a serem consideradas: a) a eficiência das medidas na realização o objeto proposto; e b) o grau de restrição ao direito fundamental atingido (SILVA, 2002, p.171).

$\mathrm{Na}$ espécie, para promover o fim de maximizar a efetividade das normas penais incriminadoras, os meios alternativos hipoteticamente elegíveis se mostram tão eficientes quanto a vedação da prescrição retroativa, pela pena concretizada, entre a data do fato e o recebimento da denúncia ou queixa, mas o aumento de penas e/ou de todos os prazos prescricionais indubitavelmente atingiria, com maior intensidade, o direito de liberdade.

Por sua vez, a criação de novos marcos interruptivos da prescrição na fase a investigação preliminar não afetaria o direito de liberdade e modo menos intenso que a medida legislativa ora hostilizada.

Desta feita, o art. $110, \$ 1^{\circ}$, do Código Penal, na redaçáo dada pela Lei $\mathrm{n}^{\mathrm{o}}$ 12.234/2010, supera, com êxito, o exame da necessidade.

\subsection{Da Proporcionalidade em Sentido Estrito}

O último exame é o da proporcionalidade em sentido estrito, de acordo com o qual: 
“(..) a importância da intervenção no direito fundamental deve estar justificada pela importância da realização do fim perseguido pela intervenção legislativa.

Esta definição significa que as vantagens que se obtêm mediante a intervenção legislativa no direito fundamental devem compensar os sacrifícios que esta implica para os seus titulares e para a sociedade em geral. Tratase de uma comparação entre a importância da intervenção no direito fundamental e a importância da realização do fim legislativo, com o objetivo de fundamentar uma relação de precedência entre aquele direito e este fim”. (PULIDO, 2007, p.763)

Esse exame, segundo Humberto Ávila (2011, p.185),

“(...) exige a comparação entre a importância da realização do fim e a intensidade da restrição aos direitos fundamentais. A pergunta que deve ser formulada é a seguinte: $\mathrm{O}$ grau de importância da promoção do fim justifica o grau de restrição causado aos direitos fundamentais? Ou, de outro modo: As vantagens causadas pela promoção do fim são proporcionais às desvantagens causadas pela adoção do meio? A valia da promoção do fim corresponde à desvalia da restrição causada?”.

Trata-se, desta forma, de um controle de sintonia fina, que indica a justeza da solução alvitrada ou a necessidade de sua revisão (MENDES e BRANCO, 2014, p. 227).

Essa etapa consiste em um sopesamento entre os direitos envolvidos, a fim e evitar que uma medida estatal, a despeito de adequada e necessária, restrinja direitos fundamentais além daquilo que a realização do objetivo perseguido seja capaz de justificar (SILVA, 2002, p.175).

Dito e outro modo, os benefícios que derivam da proteção penal, da perspectiva do bem juridicamente tutelado, hão de compensar os custos que necessariamente derivam do sacrifício (SANCHÍS, 2009, p. 273).

Diversidade das regras, cujas antinomias ocorrem na dimensão da validade, as colisóes entre princípios se dão na dimensão do peso.

Quando princípios colidem, estabelecendo consequências jurídicas inconciliáveis, um deles terá que ceder, mas isso não significa que o princípio cedente será declarado inválido. Será mister a fixação de relaçóes condicionadas de precedência, ou seja, a determinação das condiçôes sob as quais um princípio terá precedência em face de outro (ALEXY, 2012, p. 593).

Para se estabelecer a relação de procedência de um princípio sobre outro, aplica-se, d acordo com Robert Alexy (2012, p. 594), a denominada lei do sopesamento: quanto maior o grau de afetação de um princípio, tanto maior terá que ser a importância da satisfação do outro. O sopesamento compreende avaliar: i) o grau de afetação de um dos 
princípios. ii) a importância da satisfação do princípio colidente; e iii) se a importância da satisfação do princípio colidente justifica a afetação do outro princípio.

Cuida-se, em outras palavras, de estabelecer quais são as razóes suficientes para que a um princípio se atribua um peso maior que ao outro, contra o qual colide.

Torna-se imprescindível, aqui, fixar a magnitude, isto é, o peso, da importância dos direitos fundamentais afetados, e maneira negativa e positiva, pela intervenção legislativa (PULIDO, 2007, p.766).

Para tanto, é possível recorrer-se a uma escala de graus de intensidade da afetação de um princípio e da importância da satisfação do outro, para fundamentar as premissas da argumentação jurídica a ser desenvolvida.

Embora haja certo grau de discricionariedade na elaboração dessa escala, o modelo mais comumente utilizado, segundo Robert Alexy (2012, p. 594), é o triádico, de res níveis ou graus de intensidade: leve (= fraco, reduzido, débil), médio e grave (= forte, sério, elevado). Nada obstaria, ainda, o recurso a uma escala mais refinada, com nove graus ou níveis (o chamado modelo triádico duplo), obtidos mediante a aplicação daqueles três graus a si mesmos, a fim de superar eventuais impasses de enquadramento da escala triádica simples: a) levíssima (=leve/leve); b) moderadamente leve (= leve/média); c) leve quase moderada (= leve/grave); d) moderada tendente para o leve (= moderada/leve); e) moderada propriamente dita (= moderada/moderada); $\mathrm{f})$ moderada quase séria (= moderada/ grave); g) levemente séria (= grave/leve); h) moderadamente séria (= grave/moderado); e i) seríssima (= grave/grave).

Poder-se-ia também, ao invés da utilização da escala triádica (graus leve, médio e grave), atribuir elementos numéricos crescentes $(1,2,3)$ aos níveis de intensidade da afetação de um princípio e da satisfação do outro, correspondentes àqueles graus, para melhor controlabilidade da argumentação empregada ao sopesamento (2012, p. 593).

De qualquer forma, como ressalta Virgílio Afonso da Silva (2002, p. 175), é mister te presente que:

\footnotetext{
"não é possível pretender alcançar, com o procedimento de sopesamento, uma exatidão matemática, nem substituir a argumentação jurídica por modelos matemáticos e geométricos. Esses modelos podem, quando muito, servir de ilustração, pois a decisão jurídica não é nem uma operação matemática, nem puro cálculo. Mais importante que buscar fórmulas matemáticas é a busca de regras de argumentação, critérios de valoração ou a fundamentação de precedências condicionadas".
}

Estabelecidas as premissas do raciocínio a ser empregado, passo ao sopesamento propriamente dito dos princípios ora em conflito. 
O grau de afetação do direito de liberdade pela Lei $n^{\circ} 12.234 / 2010$, ao inviabilizar a extinçáo da punibilidade do agente entre a data do fato e o recebimento da denúncia com base na pena aplicada, ao nosso sentir, pode ser considerado médio, ou, numa escala mais refinada, situado entre médio e grave. O grau mais alto da escala (grave) somente seria atingido se as penas cominadas aos crimes e/ou todos os prazos prescricionais fossem majorados.

Por sua vez, o grau de importância da satisfação dos princípios colidentes - dever estatal de proteção de direitos fundamentais da sociedade, efetividade da norma penal e da tutela jurisdicional -, à vista das razóes já expedidas anteriormente, pode ser classificado como intenso ou forte.

Logo, as fortes razões para a intervenção legislativa - maximizar o cumprimento do dever estatal de proteção de direitos fundamentais da sociedade, a efetividade da norma penal e da tutela jurisdicional -, justificam o grau de restrição imposta ao direito de liberdade, tanto mais que os outros meios à disposição do legislador (aumento de penas ou de todos os prazos prescricionais) poderiam afetá-lo de modo muito mais intenso.

A título de argumentaçáo, ainda que se reputasse forte o grau de afetação da liberdade de locomoção, haveria uma equivalência com o grau de importância da realização dos princípios colidentes. E, se a razão para uma intervenção é tão forte quanto a razão contra ela, a intervenção não é desproporcional (ALEXY, 2012, p. 608).

Desta feita, o artigo $110, \$ 1^{\circ}$, do Código Penal, na redação dada pela Lei $\mathrm{n}^{\circ}$ 12.234/2010, é proporcional em sentido estrito.

Nem se alegue que a alteração legislativa em questão importaria em violação ao conteúdo essencial do direito de liberdade, haja vista que, de acordo com Virgílio Afonso da Silva, se a constitucionalidade de uma restrição a um direito fundamental garantido por um princípio depende sobretudo de sua fundamentaçáo constitucional, e se essa fundamentação é controlada a partir da regra da proporcionalidade, pode-se dizer que toda restrição proporcional é constitucional. Referido autor resume o seu raciocínio no seguinte silogismo:

“i. restrições que atingem o conteúdo essencial são inconstitucionais;

ii. restriçóes que passem pelo teste da proporcionalidade são constitucionais;

iii. restriçôes que passem pelo teste da proporcionalidade não atingem o conteúdo essencial”. (SILVA, 2002, p. 206)

Náo se pode deslembrar que a proporcionalidade, como pondera Luís Prieto Sanchis, deve ser aplicada com prudência, haja vista que, por força da separação dos Poderes, não se pode jugular a soberania política do Parlamento e sua legitimidade democrática. 
Isso, por óbvio, não significa renunciar a um controle de constitucionalidade de ordem material nem outorgar ao legislador discricionariedade política absoluta - o que importaria na criação de um espaço isento, de uma "lacuna de constitucionalidade" -, mas sim validar opçóes políticas legítimas (SANCHÍS, 2003, p.288).

O Parlamento tem competência para configurar ou conformar as disposiçóes constitucionais e a faculdade de escolher o conteúdo das leis, dentre um amplo número de alternativas de ação. Representa, ainda, o órgão que, em princípio, deve solucionar as colisóes de direitos fundamentais e harmonizar as diversas exigências normativas que emanam da Constituição (PULIDO, 2007, p.498).

A Lei $n^{\circ} 12.234 / 10$, portanto, se insere na liberdade de conformação do legislador, que tem legitimidade democrática para escolher os meios que reputar adequados para a consecuçáo de determinados objetivos, desde que não lhe seja vedado pela Constituição e nem viole a proporcionalidade, a fim de, ao restringir direitos, realizar uma tarefa de concordância prática justificada pela defesa de outros bens ou direitos constitucionalmente protegidos (CANOTILHO, 1998, p.417).

\section{Da Razoabilidade da Lei $\mathrm{n}^{\circ} \mathbf{1 2 . 2 3 4 / 1 0}$ e seu Suporte Empírico}

A razoabilidade, segundo Humberto Ávila (2011, p.163), constitui um postulado normativo aplicativo, na medida em que estrutura a aplicação de outras normas, notadamente regras. Dentre as suas várias acepçôes, a razoabilidade é empregada como diretriz que exige uma vinculação das normas jurídicas com o mundo ao qual elas fazem referência, com as condiçóes externas de sua aplicação, seja reclamando a existência de um suporte empírico e adequado a qualquer ato jurídico, seja demandando uma relação congruente entre a medida adotada e o fim que ela pretende atingir. Na primeira hipótese, afastam-se motivos arbitrários; na segunda hipótese, exige-se uma correlação entre o critério distintivo utilizado pela norma e a medida por ela adotada. Não se trata de uma análise de relação entre meio e fim, mas entre critério e medida. O legislador, portanto, não pode eleger uma causa inexistente ou insuficiente para a atuação estatal, sob pena de violar a exigência de vinculaçáo à realidade. Os princípios constitucionais do Estado de Direito (art. $1^{\circ}$ ) e do devido processo legal (art. 5º, LIV) impedem a utilização de razóes arbitrárias.

Embora diversas as suas estruturas de aplicação, como já exposto no item V supra, a razoabilidade aproxima-se, aqui, do exame da proporcionalidade na sua vertente de proibição do excesso - relembre-se que a proporcionalidade também pode ser utilizada para finalidade oposta, isto é, como proibição por defeito (CANOTILHO, 1998, p.265) ou instrumento contra a omissão ou ação insuficiente dos poderes estatais (SILVA, 2002, p.26/27)- na medida em que ambos têm por objetivo interditar o arbítrio e neutralizar o 
abuso do poder de legislar, que não pode agir de forma imoderada ( $\mathrm{HC}$ no $99.832 / \mathrm{MG}$, Segunda Turma, Relator o Ministro Celso de Mello, DJe de 31/8/12).

Sob esse prisma, não se vislumbra excesso ou imoderação na nova disciplina da prescrição da pretensão punitiva retroativa, uma vez que o dever de congruência está presente na ediçáo da Lei no $12.234 / 10$, cujo escopo declarado é evitar a impunidade.

Não creio que seja necessário, dada a sua notoriedade, lançar mão de pesquisas e relatórios para demonstrar a baixa eficiência dos fluxos do sistema de Justiça Criminal no Brasil, tanto do ponto de vista da investigação quanto da aplicação da sanção penal e sua efetiva execução.

Cito, exemplificativamente, o Relatório Nacional da Execução da Meta 2 ("A impunidade como alvo") da Estratégia Nacional de Justiça e Segurança Pública (ENASP) - cujos gestores são o Conselho Nacional de Justiça, o Conselho Nacional do Ministério Público e o Ministério da Justiça -, segundo o qual a taxa de esclarecimento de homicídios no Brasil situa-se entre 5\% e $8 \%$.

Por sua vez, a taxa de esclarecimento de roubos, no Estado de São Paulo, situa-se entre $2 \%$ e $4 \%$.

Outros dados empíricos, que demonstram a impossibilidade de se investigar, com eficiência, todos os crimes praticados, bem ilustram a vinculação da Lei no $12.234 / 10$ à realidade.

Apenas no Estado de São Paulo, de janeiro a agosto de 2014, foram instaurados 314.334 inquéritos policiais. Em 2013, foram instaurados, no total, 429.279 inquéritos policiais (dados extraídos do sítio eletrônico da Secretaria da Segurança Pública do Estado de São Paulo).

Em 2013 foram registradas, no mesmo Estado, 4.444 ocorrências de homicídio (em 2012 e 2011 foram, respectivamente, 4.836 e 4.193), 542.888 de furto (em 2012 e 2011 foram, respectivamente, 543.310 e 541.139), 257.062 de roubos (em 2012 e 2011 foram, respectivamente, 237.810 e 235.523 ) e 215.525 de furto e roubo de veículos (em 2012 e 2011 foram, respectivamente, 195.685 e 184.311).

De acordo com pesquisa do Instituto Sou da Paz, apresentada no 7o Encontro do Fórum de Segurança Pública, foram registrados no Município de São Paulo, em 2009, 159.578 boletins de ocorrência referentes a crimes de roubo e extorsão. Desse universo, foram instaurados 9.759 inquéritos, dos quais apenas 6.778 foram relatados identificando a autoria do crime. Em 2010, foram 145.926 boletins de ocorrência de crimes daquela espécie, em relação aos quais foram instaurados 9.107 inquéritos, dos quais somente 6.510 foram relatados identificando a autoria do crime. Em 2011, foram 150.299 boletins de ocorrência, motivando a instauração de 8.944 inquéritos, dos quais somente 6.129 foram relatados identificando a autoria do crime. 
Somem-se, a essas estatísticas parciais, milhares de outros ilícitos penais (tráfico de drogas, crimes diversos contra a pessoa, o patrimônio, a dignidade sexual, a fé pública, a administração pública, crimes ambientais etc.), de boletins de ocorrência e de inquéritos policiais, inclusive relativos a anos anteriores, que, sucessivamente, se cumulam, para investigação.

Diante desses números, encontráveis em todas as esferas (federal, estadual e distrital), e da impossibilidade financeira de o Estado atender, em sua plenitude, a todas as outras demandas sociais, importaria dissociação da realidade pretender que os órgãos da persecução devessem ser providos com toda a estrutura material e humana para investigar, com eficiência e celeridade, todo e qualquer crime praticado.

A avassaladora massa de delitos a investigar é, indiscutivelmente, uma das causas eficientes da impunidade, dada a demora - quando não verdadeira impossibilidade - no seu esclarecimento, na verificação da responsabilidade penal do imputado e na puniçáo dos culpados, assim reconhecidos definitivamente como tais.

Acresça-se a esse contexto a chamada "cifra negra" ou "campo obscuro da delinquência”, que se define, segundo Raúl Cervini (2002, p.182),

“(...) como a diferença existente entre a criminalidade real (quantidade de delitos cometidos num tempo e lugar determinados) e a criminalidade aparente (criminalidade conhecida pelos órgáos de controle), que indica, comprovadamente, acerca de alguns delitos, um percentual substancial em que não é aplicado o sistema penal e que, em alguns casos, é absoluto, circunstância que debilita a sua própria credibilidade, ou seja, a credibilidade de todo o sistema penal". Dentre as inúmeras motivaçóes para a sub-notificação de crimes, insere-se a falta de confiança na efetividade do sistema de justiça criminal”.

Sob esse aspecto, se é certo que a maior efetividade da tutela jurisdicional penal constitui um dos instrumentos idôneos para minimizar a sub-notificação de crimes, por outro, paradoxalmente, teria o efeito de, aproximando a criminalidade aparente da criminalidade real, contribuir para um maior congestionamento do sistema de justiça criminal, retardando ainda mais a tutela jurisdicional final e a execução de eventual sanção imposta.

Vittorio Grevi, ao tratar do giusto processo, aduz que o objetivo institucional do processo é verificar os fatos e responsabilidade do agente, a fim de assegurar o exercício da jurisdição penal, o que, em si, é uma finalidade neutra. Embora o processo penal não tenha, de forma imediata, uma finalidade de defesa social, não se pode negar que, como instrumento exclusivo de atuação da lei penal, de forma mediata, cumpre essa finalidade, quando advém uma sentença condenatória.

Ao ver de Grevi (2000, p.10), se não existe justiça sem garantias processuais, também não há justiça quando o processo não consegue se aproximar do seu resultado natural, 
que é uma sentença justa - e menos ainda, acrescento, quando essa mesma sentença justa acaba por não ter efetividade alguma.

No Estado Democrático de Direito, fazer justiça significa atingir o equilíbrio entre dois valores relevantes que são inerentes ao processo penal: assegurar a paz social pela punição dos crimes e garantir a todos os indivíduos o respeito à sua liberdade individual (SCARANCE FERNANDES, 2008, p.532).

Assim, em havendo uma condenação definitiva, a justiça somente se concretiza com a sua efetiva execução.

Justo, pois, é assegurar o cumprimento de uma pena justa, proporcional à gravidade do fato e à culpabilidade do agente, imposta por meio do justo processo legal.

Verbera-se também que a Lei no $12.234 / 10$ constituiria parte do direito penal simbólico.

Nesse ponto, indaga Claus Roxin (2012, p.47):

"São legítimas tais leis penais simbólicas? Não se pode responder a esta pergunta univocamente, com um sim ou um não, pois é claro que todos os dispositivos penais almejam não só impedir e punir determinados delitos, como também atuar sobre a consciência jurídica da população. Quando o Estado se dispóe a proteger a vida, a integridade física, a propriedade etc., tenta ele fortalecer na população o respeito por estes valores. Nisto não há nada de problemático. Esta prevenção geral positiva é, muito mais, uma das finalidades reconhecidas do direito penal. Assim, tão importante quanto atuar sobre a consciência da população, a legitimidade depende de se o dispositivo se mostra realmente necessário para a efetiva proteção de uma convivência pacífica”.

Nesse sentido, a vedação à prescrição da pretensão punitiva, na modalidade retroativa, pela pena concretizada, entre a data do fato e a data do recebimento da denúncia ou queixa, constitui legítimo instrumento de política criminal do legislador - assim entendida como critério empregado no tratamento da criminalidade (MIR PUIG, 2002, p. 57).

Não se trata de um incremento da repressão, pela via do aumento indiscriminado de penas ou prazos prescricionais, mas de se conferir, repise-se, efetividade às sançóes penais já existentes.

Tanto isso é verdade que a mesma Lei no $12.234 / 10$, ora vergastada, também aumentou de 2 (dois) para 3 (três) anos o prazo de prescrição, quando o máximo da pena cominada for inferior a um ano (art. 109, VI, CP) e, quanto a esse aspecto, nunca se questionou a sua constitucionalidade.

E qual a razão para o legislador aumentar, especificamente, esse prazo prescricional? 
Mais uma vez, a observação empírica de que o prazo anterior de dois anos, dados a massa de crimes praticados, a estrutura dos órgãos da persecução penal e o inegável congestionamento do Poder Judiciário, era insuficiente para uma resposta penal efetiva.

\section{Do Princípio da Isonomia (art. 50 ${ }^{\circ}$ II, CF)}

A alteração legislativa ora hostilizada não viola o princípio da isonomia. $\mathrm{O}$ art. 110, $\$ 1^{\circ}$, do Código Penal, na nova redação conferida pela Lei no $12.234 / 10$, dado o seu caráter abstrato e geral, não individualiza e nem discrimina o seu destinatário. Todo e qualquer crime, e, por via de consequência, todo e qualquer agente, indistintamente, subsume-se na sua hipótese normativa.

O fato de se admitir a prescrição da pretensão punitiva, na modalidade retroativa, pela pena concretizada, entre o recebimento da denúncia ou queixa e marcos interruptivos posteriores, mas não se admiti-la entre a data do fato e aquele primeiro marco interruptivo da prescrição (art. 117, I, CP), é questão de política criminal, que também não vulnera o princípio da isonomia.

Para Celso Antônio Bandeira de Mello (2009, p.37),

"o ponto nodular para o exame da correção de uma regra em face do princípio isonômico reside na existência ou náo de correlaçáo lógica entre o fator erigido em critério de discrímen e a discriminação legal decidida em função dele".

Em suas palavras, para que um discrímen legal seja convivente com a isonomia, impende que concorram quatro elementos:

a) que a desequiparação não atinja de modo atual e absoluto, um só indivíduo;

b) que as situações ou pessoas desequiparadas pela regra de direito sejam efetivamente distintas entre si, vale dizer, possuam características, traços, nelas residentes, diferençados;

c) que exista, em abstrato, uma correlação lógica entre os fatores diferenciais existentes e a distinção de regime jurídico em função deles, estabelecida pela norma jurídica;

d) que, in concreto, o vínculo de correlação supra-referido seja pertinente em função dos interesses constitucionalmente protegidos, isto é, resulte numa diferenciação de tratamento jurídico fundada em razão valiosa ao lume do texto constitucional - para o bem público" (BANDEIRA DE MELLO, 2009, p.41).

$\mathrm{Na}$ espécie, qual o discrímen que subjaz à Lei no $12.234 / 10$ ? Entendemos, a imputação. 
O legislador, legitimamente, elegeu o recebimento da denúncia ou queixa, peças nas quais se individualiza e se formaliza a imputação, como o elemento que autoriza discriminar o momento em que a prescrição deixa de ser regulada pela pena em abstrato para ser regulada pela futura pena aplicada na sentença, e essa opção se justifica pela natureza e finalidade da investigação preliminar.

A fase da investigação preliminar visa à obtenção de todos os elementos necessários à formação da opinio delicti, sem que se possa precisar, de antemão, diante do influxo de inúmeras e incontroláveis variáveis, o tempo necessário à apuração do fato e sua autoria.

Uma vez reunidos os elementos de informação imprescindíveis à formação da opinio delicti e instaurada a ação penal, não mais se trata de investigar fatos ainda não perfeitamente delineados e sua autoria, mas de provar - ônus que recai inteiramente sobre o órgão acusatório - os fatos em que se lastreia a imputação. $\mathrm{Na}$ fase da ação penal, há uma imputação formalizada e um processo instaurado contra um réu individualizado.

Existe, portanto, uma correlação lógica entre esses fatores diferenciais e o regime jurídico distinto da prescrição retroativa, pela pena aplicada, eleito pelo legislador.

Ainda que a fase da investigação preliminar deva, tanto quanto possível, reger-se pelo princípio da duração razoável, não há como submetê-la ao jugo de um limite temporal pré-determinado, dada a sua própria vocaçáo, que é apurar a existência de uma infração penal e sua autoria.

A despeito da notória insuficiência de recursos humanos e materiais dos órgãos da persecução penal para investigar todos os crimes que lhes são comunicados, a demora na conclusão do inquérito policial ou instrumento equivalente da fase da investigação preliminar não é imputável, única e exclusivamente, a deficiências estruturais.

Há investigaçóes que, por sua própria natureza, são complexas, como as relativas, v.g., a crimes contra a administração pública, contra o sistema financeiro nacional, de lavagem de dinheiro ou que envolvam organizaçóes criminosas, com uma intrincada cadeia de fatos e agentes a desvendar.

A investigação, em sentido amplo, compreende amealhar todos os elementos de informação possíveis para a formação do convencimento do titular da açáo penal a respeito da prática de uma infração penal e sua autoria, o que implica, quando relevante e pertinente, localizar e inquirir vítimas e testemunhas, realizar interceptaçóes telefônicas, buscas e apreensões, quebras de sigilo bancário e fiscal de pessoas físicas e jurídicas, perícias etc. Há dados a serem requisitados, compilados, cruzados e analisados, em conjunto com inúmeros outros elementos de informação.

Em outras palavras, a tardança no encerramento da investigação não deriva necessariamente de deficiência estrutural ou negligência dos órgãos da persecução, mas pode ser ínsita à complexidade dos fatos em apuração. 
Ademais, a própria existência do fato pode vir a ser tardiamente descoberta - como, aliás, sói acontecer em crimes de maior complexidade.

Nesse diapasão, subverteria a ordem das coisas exigir que a duração de toda investigação devesse se balizar pelo prazo de prescrição relativo à pena mínima cominada ao crime investigado, a fim de se evitar que, no caso de futura condenação, viesse a ser reconhecida a prescrição da pretensão punitiva retroativa, pela pena aplicada, entre a data do fato e o recebimento da acusação, uma vez que a efetividade das normas penais e da tutela jurisdicional é um valor constitucional a se resguardar.

Os limites temporais da investigação, repita-se, não podem ser condicionados a um prognóstico de imposição de pena no mínimo legal. Para bem cumprir sua finalidade, a investigação poderá demandar o tempo que se fizer necessário para a apuração do fato, suas circunstâncias e autoria, respeitado o prazo de prescrição pela pena máxima em abstrato cominada ao delito.

Enquanto o titular da ação penal pública não vir reunidos todos os elementos necessários à formação do seu convencimento, não há como se coarctar a investigaçáo, salvo, v.g., falta de justa causa ou a presença de causa de extinção da punibilidade, sob pena de frustrar-se o exercício de uma função institucional do Ministério Público, constitucionalmente assegurada (art. 129, I, CF).

Em suma, pelo imperativo da ausência de uma imputação formalizada pelo titular da ação penal, a prescrição da pretensão punitiva, entre a data do fato e o recebimento da acusação, deve sempre reger-se, de acordo com a legítima opção do legislador, pela pena máxima em abstrato cominada ao crime.

\section{Os Princípios da Culpabilidade e da Individualização da Pena (art. 50, XLVI, CF)}

A culpabilidade, como sabido, é fundamento e medida da pena. Como pressuposto de aplicação da pena, a culpabilidade é um juízo de reprovação sobre quem, agindo com dolo ou culpa, praticou um fato típico e antijurídico. Os elementos da culpabilidade que envolve, nas palavras de Günther Jakobs (2012, p.16), volição e cognição, um querer e um conhecer - são a imputabilidade, a potencial consciência da ilicitude e a exigibilidade de conduta diversa.

Como medida da pena, a culpabilidade interdita o excesso na individualização da pena e impóe limites à sua fixaçáo, a exigir que não seja superior à gravidade do fato nem ao grau de responsabilidade do agente.

Não se divisa, portanto, qualquer incompatibilidade entre culpabilidade e individualização, de um lado, como juízo de reprovação e medida da pena, e, de outro, vedação à 
prescrição da pretensão punitiva, na modalidade retroativa, pela pena já individualizada, para garantir a sua efetividade.

\section{Por uma Razoável Duração do Processo (art. 5², LXXVIII, CF)}

A garantia constitucional da razoável duração do processo (art. 5º LXXVIII, CF), que compreende processos judiciais de qualquer natureza e se estende ao âmbito administrativo, deve ser analisada sob dúplice aspecto: i) o direito a que qualquer processo (civil, penal, trabalhista) se desenvolva em prazo razoável ou sem dilaçóes indevidas, e ii) o direito do réu ou imputado preso à revogação da prisão cautelar, caso não seja julgado em prazo razoável ou sem dilaçóes indevidas (BADARÓ, 2012, p.34).

No processo penal, como corolário dessa garantia, o ideal seria que toda investigação, preso ou solto o investigado, fosse concluída no prazo mais célere possível.

Todavia, como já exposto no item VII supra, considerando-se que inúmeras variáveis podem interferir na sua tramitação, a investigação, para bem cumprir sua finalidade, poderá demandar o tempo que se fizer necessário para apuração do fato criminoso e de sua autoria, respeitado o prazo de prescrição da pretensão punitiva.

Corroborando essa assertiva, não existe, no ordenamento jurídico brasileiro, previsão para trancamento de uma investigação preliminar por mera tardança no seu encerramento, cuja consequência, no limite, somente pode ser a prescrição da pretensão punitiva pela pena em abstrato cominada ao crime investigado.

Nesse diapasão, o principal foco da garantia da razoável duração do processo deve ser a tutela da liberdade de locomoção do investigado preso, que náo pode permanecer custodiado cautelarmente por prazo irrazoável.

Se assim o é, não se vislumbra qualquer incompatibilidade entre a garantia da razoável duração do processo e a vedação à prescrição da pretensão punitiva, na modalidade retroativa, pela pena aplicada.

Outrossim, segundo Mario Chiavario (2012, p.290), não há dúvida de que uma maior brevidade dos prazos prescricionais poderia influir positivamente sobre o princípio da duração razoável do processo. Mas se é verossímil que uma "prescrição breve" possa contribuir para estimular a condução célere da investigação e do processo, a fim de não se verem anulados, pela prescrição, os resultados do trabalho já executado, a fixação de lapsos prescricionais inadequados em relação aos recursos humanos e materiais do Estado tem dois efeitos negativos: i) a distorção que a prescrição gera nos objetivos do princípio da duração razoável do processo, que não visa tornar inútil o trabalho de verificação dos crimes mas, sobretudo, torná-lo mais eficaz, seja no sentido de conduzir a uma tempestiva repressão, seja no de não manter o imputado sob o pesadelo de uma 
acusação, particularmente se inocente; e ii) o recurso a expedientes dilatórios pela parte, para alcançar a prescrição.

A esse respeito, Vittorio Grevi (2012, p.XLII) adverte que a prescrição tem se transformado numa espécie de "âncora de salvação", numa "absolvição, pela extinção do crime, arrancada com os dentes".

O legislador, seguramente atento a essa realidade, optou por não mais prestigiar um sistema de prescrição da pretensão punitiva retroativa, pela pena aplicada, que culminava por esvaziar a efetividade da tutela jurisdicional penal.

\section{Breve Análise da Legislação Espanhola em Relação a Matéria de Prescri- ção penal}

A prescrição da pretensão punitiva, na modalidade retroativa, pela pena aplicada na sentença, constitui peculiaridade do Código Penal brasileiro, que não encontra similar, até onde é possível discernir, em nenhum outro ordenamento jurídico.

O Código Penal Espanhol, no art. 131, ao tratar da "prescrição do delito", prevê que os crimes prescrevem em 20 anos, quando a pena máxima cominada for de 15 anos ou mais de prisão; em 15 anos, se a pena máxima for a de prisão entre 15 e 10 anos; aos 10 anos, quando a pena máxima for prisão superior a 5 anos e não superior a 10 , e em 5 anos para os demais crimes, exceto injúria e calúnia, que prescrevem em um ano. ${ }^{1}$

A legislação espanhola trata com maior rigor a prescrição das penas impostas por sentença definitiva, uma vez que, no art. 133 daquele Código Penal, determina que prescrevem em 30 anos as penas superiores a 20 anos; em 25 anos, as de prisão iguais ou superiores a 15 anos e que náo excedam a 20; em 20 anos, as de prisão superiores a 10 e inferiores a 15 anos; em 15 anos, as de prisão por mais de cinco e que náo excedam a 10; em 10 anos, as demais penas graves; em 5 anos, as penas menos graves, e em 1 ano, as penas leves. ${ }^{2}$

1 De acordo com o Código Penal Espanhol: Artículo 130. La responsabilidad criminal se extingue (...) 6 . Por la prescripción del delito. 7. Por la prescripción de la pena o de la medida de seguridad. (...) Artículo 131. 1. Los delitos prescriben: A los 20 años, cuando la pena máxima seńalada al delito sea prisión de 15 o más años. A los 15 , cuando la pena máxima señalada por la ley sea inhabilitación por más de 10 años, o prisión por más de 10 y menos de 15 ańos. A los 10, cuando la pena máxima seńalada por la ley sea prisión o inhabilitación por más de cinco años y que no exceda de 10. A los cinco, los demás delitos, excepto los de injuria y calumnia, que prescriben al ańo. (...)

2 Acerca do mesmo tema: Artículo 133. 1. Las penas impuestas por sentencia firme prescriben: A los 30 años, las de prisión por más de 20 años. A los 25 años, las de prisión de 15 o más años sin que excedan de 20. A los 20, las de inhabilitación por más de 10 años y las de prisión por más de 10 y menos de 15 . A los 15 , las de inhabilitación por más de seis años y que no excedan de 10, y las de prisión por más de cinco años y que no excedan de 10. A los 10, las restantes penas graves. A los cinco, las penas menos graves. 
Como se observa, em todas essas legislações estrangeiras a prescrição da pretensão punitiva (ora denominada de "prescrição da ação penal", ora de "prescrição do procedimento criminal"), regula-se, invariavelmente, pela pena máxima abstratamente cominada ao crime, e nunca pela pena aplicada na sentença, a qual regula, tão somente, a prescriçáo da pretensão executória.

Dito de outro modo, a vocação da pena aplicada na sentença é regular, com efeitos ex nunc, a prescrição da pretensão executória após o trânsito em julgado da condenação, não a prescrição da pretensão punitiva, com efeitos ex tunc.

Seria lícito afirmar que esses ordenamentos jurídicos violam a proporcionalidade em sentido amplo e os princípios da dignidade da pessoa humana, da humanidade da pena, da culpabilidade, da individualização da pena, da isonomia e da razoável duração do processo, pelo fato de não reconhecerem, em nenhuma hipótese, a prescrição da pretensão punitiva, na modalidade retroativa, entre data do fato e recebimento da imputação, pela pena aplicada?

Parece-nos que não.

Cuida-se de mais uma demonstração inequívoca de que, embora a pena justa para o crime seja aquela imposta na sentença, é questão de política criminal, a cargo do legislador, estabelecer se a prescrição, enquanto não transitada em julgado a condenaçáo, deve ser regulada pela pena abstrata ou concreta, bem como, nesta última hipótese, definir a extensão dos seus efeitos ex tunc.

Se, na lição de Hans-Heinrich Jeschek (1981, p.30), "nem tudo o que aparece como eficaz é justo", penso que a alteração legislativa, ora vergastada, mostra-se constitucional, justa e eficaz, razão por que deve ser prestigiada.

\section{Considerações (Sempre) Parciais}

Diante das questôes aqui discutidas, entendemos que ainda é possível a prescrição retroativa no período entre o recebimento da denúncia ou queixa e a publicação da sentença, sendo proibida entre a data do fato e a do recebimento da acusação formal, é infringir o princípio constitucional da proporcionalidade. A aceitar-se, será permitir flagrante desproporção na consideração dos períodos prescricionais de igual extensão temporal.

\section{Referências}

ALEXY, Robert. Teoria dos direitos fundamentais. Trad. Virgílio Afonso da Silva. 2a ed. São Paulo: Malheiros, 2012. 
ÁVILA, Humberto. Teoria dos princípios - da definição à aplicação dos princípios jurídicos. 12a ed. ampl. - São Paulo: Malheiros, 2011.

BADARÓ, Gustavo Henrique Righi Ivahy. Processo Penal. Rio de Janeiro: Campus

BANDEIRA DE MELLO, Celso Antônio. (Conteúdo jurídico do princípio da igualdade. $3^{\mathrm{a}}$ ed.

BARROS, Suzana de Toledo. O principio da proporcionalidade e o controle de constitucionalidade de leis restritivas de direitos fundamentais. 2. ed. Brasília: Editora Brasília Jurídica, 2000.

BARROSO, Luis Roberto. O direito constitucional e a efetividade de suas normas limites $e$ possibilidades da Constituição Brasileira. 9a ed. - Rio de Janeiro: Renovar, 2009.

BOROWSKI, Martin. La estructura de los direitos fundamentais. Trad. PULIDO, Carlos Bernal. Bogotá: Universidad Externado de Colombia, 2003.

BRUNO, Aníbal. Direito penal. Tomo I. 5ª ed. - Rio de Janeiro: Forense, 2005. . Direito penal. Tomo III. $3^{\text {a }}$ ed. - Rio de Janeiro: Forense, 1967.

CANOTILHO, José Joaquim Gomes. Direito Constitucional e teoria da constituição. Coimbra: Almedina, 1998.

CERVINI Raúl. Os processos de descriminalização. 2a ed. - São Paulo: Editora Revista dos Tribunais, 2002.

CHIAVARIO, Mario. Diritto processuale penale - profilo istituzionale. $5^{\text {a }}$ ed. Torino: Utet Giuridica, 2012.

COSTA JUNIOR, Paulo José da. Prefácio à obra Crime e castigo. Reflexóes politicamente incorretas. 2a ed. - Campinas: Millenium Editora, 2002.

GAVIÃO FILHO, Anizio Pires. Colisão de direitos fundamentais, argumentação e ponderação. Porto Alegre: Livraria do Advogado, 2011.

GREVI, Vittorio. Alla ricerca di un processo penale giusto itinerari e prospettive . Milano: Giuffrè, 2000.

. Compendio di procedura penale. 6a ed. Pádua: CEDAM.

GUERRA FILHO, Willis Santiago. Princípio da proporcionalidade e teoria do direito. In: Estudos em homenagem a Paulo Bonavides. Org. Eros Roberto Grau e Willis Santiago Guerra Filho. 1a ed. - São Paulo: Malheiros, 2001.

JAKOBS, Günther. Fundamentos do direito penal. Trad. André Luís Callegari. 2a ed. São Paulo: Editora Revista dos Tribunais, 2012.

JESCHEK, Hans-Heinrich. Tratado de derecho penal. Parte general. Volume I. Trad. Santiago Mir Puig e Francisco Muñoz Conde. Barcelona: Bosch Casa Editorial, 1981. 
KELSEN, Hans. Teoria pura do direito. São Paulo: Martins Fontes, 1991.

MARQUES, José Frederico. Tratado de direito penal. Vol. III. 1a ed. atualiz. - Campinas: Millennium, 1999.

MENDES, Gilmar Ferreira. Curso de Direito Constitucional. 9a ed., rev. e atual. - São Paulo: Saraiva, 2014.

MENDES, Gilmar Ferreira. BRANCO, Paulo Gustavo Gonet. Curso de direito constitucional. 9a ed. - São Paulo: Saraiva, 2014, p. 160.

MIR PUIG, Santiago, Derecho penal. Derecho penal. Parte general. 6a ed. - Barcelona: Editorial Repertor, 2002.

PULIDO, Carlos Bernal. El principio de proporcionalidad y los derechos fundamentales. $3^{\mathrm{a}}$ ed. atual. Madrid: Centro de Estudios Políticos y Constitucionales, 2007.

ROXIN, Claus. Estudos de direito penal. trad. Luís Greco. 2a ed. - São Paulo: Renovar, 2012.

SANCHÍS, Luís Prieto. Justicia constitucional y derechos fundamentales. Madrid: Editorial Trotta, 2009.

SCARANCE FERNANDES, Antônio. Efetividade, processo penal e dignidade humana. In: MIRANDA, Jorge; SILVA, Marco Antônio Marques da (coordenação). Tratado luso-brasileiro da dignidade humana. São Paulo: Quartier Latin, 2008.

SERRANO, Nicolas Gonzalez-Cuellar. Proporcionalidad y derechos fundamentales en el proceso penal. Madrid: Editorial Colex, 1990.

SILVA, Virgílio Afonso da. O proporcional e o razoável, Revista dos Tribunais, São Paulo, v. 798, abril, 2002. 